\title{
Nanoimaging of ssRNA: Genome Architecture of the Hepatitis C Virus Revealed by Atomic Force Microscopy
}

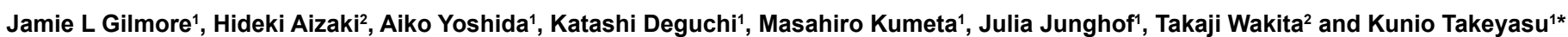

${ }^{1}$ Laboratory of Plasma Membrane and Nuclear Signaling, Kyoto University Graduate School of Biostudies, Yoshida-Konoe, Sakyo-ku, Kyoto 606-8501, Japan ${ }^{2}$ Virus Division II, National Institute of Infectious Diseases, Toyama, Shinjuku-ku, Tokyo 162-8640, Japan

\begin{abstract}
The complex structures that RNA molecules fold into play important roles in their ability to perform various functions in the cell. The structure and composition of viral RNA influences the ability of the virus to implement the various stages of the viral lifecycle and can influence the severity of the virus effects on the host. Although many individual secondary structures and some tertiary interactions of the Hepatitis $C$ virus genome have previously been identified, the global $3 \mathrm{D}$ architecture of the full $9.6 \mathrm{~kb}$ genome still remains uncertain. One promising technique for the determination of the overall 3D structure of large RNA molecules is nanoimaging with Atomic Force Microscopy. In order to get an idea of the structure of the HCV genome, we imaged the RNA prepared in the presence of $\mathrm{Mg}^{2+}$, which allowed us to observe the compact folded tertiary structure of the viral genome. In addition, to identify individual structural elements of the genome, we imaged the RNA prepared in the absence of $\mathrm{Mg}^{2+}$, which allowed us to visualize the unfolded secondary structure of the genome. We were able to identify a recurring single stranded region of the genome in many of the RNA molecules which was about $58 \mathrm{~nm}$ long. This method opens up a whole new avenue for the study of the secondary and tertiary structure of long RNA molecules. This ability to ascertain RNA structure can aid in drawing associations between the structure and the function of the RNA in cells which is vital to the development of potential antiviral therapies.
\end{abstract}

Keywords: Hepatitis C Virus; Atomic Force Microscopy; Untranslated region

Abbreviations: HCV: Hepatitis C Virus; AFM: Atomic Force Microscopy; UTR: Untranslated Region

\section{Introduction}

$\mathrm{HCV}$ is a worldwide epidemic, with about 150 million people worldwide infected and 350,000 deaths per year [1]. There is no vaccine for hepatitis $C$ and treatments have met with limited success [2]. Given how pervasive HCV is, a better understanding of the virus may lead to important new discoveries which can help to highlight new avenues by which to treat individuals infected with the virus. Since HCV was originally cloned in 1989 [3], numerous studies have tried to understand the structure of the viral RNA, mainly in the conserved untranslated regions (UTRs) of the genome. Structural motifs that have been identified include the internal ribosome entry site (IRES) located in the 5'-UTR [4-17], the poly-U/UC region and 3'X RNA regions located in the 3'-UTR [18-24], and some stem loops in the coding region [25-29]. Additionally many long-range contacts between various regions of the genome have been reported [21,30-35]. Despite the vast number of reports on various structural features of the HCV genome, the full 3D architecture of the full genome remains uncertain.

Most techniques generally study bits and pieces of a single stranded (ss)RNA genome and hope to eventually arrive at the final global genome structure over time, or they provide data about various interactions within the molecule without providing 3D information [36]. The ability of Atomic Force Microscopy (AFM) to directly visualize the nanostructure of the whole genome in a variety of configurations in a single experiment makes it a very useful technique to assess the folded structures formed by a variety of ssRNA molecules. The usefulness of AFM for evaluating the nanometer scale architecture of biological molecules [37] was realized soon after the inception of the technology [38]. AFM has been used extensively for imaging of DNA with applications ranging from the study of DNA dynamics [39], DNA-protein interactions [40-45], to DNA origami structures [46,47].
However, techniques for obtaining reproducible ssRNA images have been slower to develop, leading to far fewer AFM imaging studies on ssRNA, although the nanometer scale resolution of AFM makes it a valuable tool for revealing the organization of ssRNA structures. Most AFM studies which have visualized ssRNA have used $\mathrm{Mg}^{2+}$ concentration of 4-10 mM [48-52]. However, a couple of early studies $[53,54]$, as well as a couple others studies of viral RNA $[55,56]$ have achieved more extended ssRNA configurations using low salt solutions. It is well documented that ions play a much larger role in the folding of RNA tertiary structures, but play a minimal role in the formation of secondary structures formed by Watson-Crick base pairing of the nucleotides in the RNA chain [57-59]. Thus, by imaging various ssRNA molecules prepared without the addition of $\mathrm{Mg}^{2+}$ ions, we should be able to get valuable information about the individual secondary structural motifs in the genome and and connectivity of the molecule.

In this study, we developed a method to observe both the secondary and tertiary structure of the full $9678 \mathrm{nt} \mathrm{HCV}$ genome with nanometer resolution using AFM. By omitting $\mathrm{Mg}^{2+}$ from the buffer used to dilute the RNA prior to AFM imaging, we were able to observe the secondary structure of the molecule. The molecules had a linear configuration with various appendages extending from the molecule. Some commonly

*Corresponding author: Kunio Takeyasu, Laboratory of Plasma Membrane and Nuclear Signaling, Kyoto University Graduate School of Biostudies, Sakyoku Yoshida-Konoe, Kyoto 606-8501, Japan, Tel/Fax: +81-75-753-6852; E-mail: takeyasu@lif.kyoto-u.ac.jp

Received January 27, 2014; Accepted February 22, 2014; Published February 24, 2014

Citation: Gilmore JL, Aizaki H, Yoshida A, Deguchi K, Kumeta M, et al. (2014) Nanoimaging of ssRNA: Genome Architecture of the Hepatitis C Virus Revealed by Atomic Force Microscopy. J Nanomed Nanotechol S5: 010. doi:10.4172/21577439.S5-010

Copyright: (c) 2014 Gilmore JL, et al. This is an open-access article distributed under the terms of the Creative Commons Attribution License, which permits unrestricted use, distribution, and reproduction in any medium, provided the original author and source are credited. 
observed structural features were present in these molecules, including one end with a $58 \mathrm{~nm}$ long single stranded region and another end with a sharp kink followed by a region with a beaded appearance lacking appendages. The single stranded region observed is likely to be the poly-U/UC motif which is conserved across HCV genomes [18-24]. The morphology of homopolymeric ssRNA was further verified by imaging an ssRNA transcript of the importin- $\beta$ coding region prepared in vitro with and without a poly(A) tail.

\section{Materials and Methods}

\section{RNA}

The JFH-1 genomic RNA (accession no. AB047639) is a $9678 \mathrm{nt}$ positive strand RNA [60]. The JFH-1 strain, belonging to genotype $2 \mathrm{a}$, is the first strain of the Hepatitis $\mathrm{C}$ virus isolated from a patient which could be successfully replicated in cell culture [61]. The JFH1 RNA used for these experiments was synthesized in vitro by T7 polymerase transcription and purified with the Zymoclean kit $[62,63]$. The polyadenylated importin- $\beta$ mRNA was prepared in vitro. Mouse cDNA for importin- $\beta$ was cloned into the pTD vector (Shimadzu Corp., Japan) and transcribed with the MEGAscript T7 kit (Ambion, USA). The RNA was polyadenylated with the Poly(A) Tailing kit (Ambion, USA) and purified by $\mathrm{LiCl}$ precipitation.

\section{AFM sample preparation}

All pieces of mica were cut with a hole punch and super-glued to a $15 \mathrm{~mm}$ metal specimen disc at least a day prior to sample deposition for AFM. The JFH-1 HCV RNA was prepared by diluting the RNA sample to $0.1-0.5 \mathrm{ng} / \mu \mathrm{L}$ in buffer $\mathrm{EB}(10 \mathrm{mM}$ Tris, $\mathrm{pH}$ 8.5) from Qiagen or in a buffer containing $20 \mathrm{mM}$ Tris, $1.5 \mathrm{mM} \mathrm{MgCl}_{2}$, and $1.5 \mathrm{mM}$ dithiothreitol (DTT). The sample was then heated to $65^{\circ} \mathrm{C}$ for $2 \mathrm{mins}$, and then kept at room temperature until deposition. Just prior to sample deposition, a piece of mica affixed to a $15 \mathrm{~mm}$ metal specimen disc was freshly cleaved and $10 \mu \mathrm{L} 10 \mathrm{mM}$ spermidine was deposited on the mica and incubated for 3.5 mins. The spermidine was then washed away by washing three times with $1 \mathrm{~mL}$ of milli-Q water immediately followed by deposition of $10 \mu \mathrm{L}$ of the RNA sample for 3.5 mins. The sample was then washed again three times with $1 \mathrm{~mL}$ of milli-Q water and dried with a stream of nitrogen. The sample was immediately used for AFM imaging.

\section{AFM imaging and analysis}

AFM imaging was performed with the Multimode AFM with a Nanoscope III or IV controller and with an E or a J scanner (Digital instruments, Inc., USA). The microscope was operated in the Tapping Mode $^{\mathrm{Tw}}$ at a scanning rate of 0.5-1.0 Hz. Rectangular silicon cantilevers with sharpened tetrahedral tips were used (OMCL AC160TS, Olympus Corp., Japan). These probes had a tip radius of about $7 \mathrm{~nm}$, a resonant frequency of about $300 \mathrm{kHz}$, and a spring constant of about $26 \mathrm{~N} / \mathrm{m}$. Images displayed in this publication were flattened in the Nanoscope (v.5.31 r1) software and exported as jpegs. Images were analyzed with the Gwyddion software (Department of Metrology, Czech Metrology Institute, Czech Republic). The raw SPM images were opened in the Gwyddion software and processed by correcting the horizontal scars, correcting lines by matching the height median, leveling the data to make facets point upwards, leveling the data by mean plane subtraction, and removing the polynomial background ( $3^{\text {rd }}$ degree). The RNA molecules were marked by selecting all molecules above a $0.15-0.20$ $\mathrm{nm}$ threshold and then removing all grains smaller then $60-70 \mathrm{px}^{2}$. The edit mask tool in the subtract selection mode was used to deselect molecules from the periphery of the image. The distributions of various grain characteristics were then exported as a raw data file and then the measure individual grain tool was used to click on each molecule and record the zero basis volume and minimum circumcircle radius of each one. The values were inserted into the Origin Lab software (OriginLab Corp., USA), plotted into histograms, and fitted with Gaussian curves to obtain the center value(s) for each histogram. The errors reflect the standard deviation of the Gaussian distribution. The contour length of the molecules was measured and height profiles were generated with the Femtoscan software (Advanced Technologies Center, Moscow, Russia). The scatterplot was plotted and fitted with a linear regression curve with the y-intercept set to 0 in Microsoft Office Excel.

\section{Results and Discussion}

\section{AFM imaging of HCV RNA tertiary structure}

In our experiments, we used the full positive-stranded ssRNA $\mathrm{HCV}$ genome which is $9678 \mathrm{nt}$ in length. When the RNA was heated for $2 \mathrm{mins}$, at $65^{\circ} \mathrm{C}$ in buffer containing $1.5 \mathrm{mM} \mathrm{MgCl}_{2}$ just prior to deposition on the mica surface for imaging, the RNA molecules had a compact morphology with a variety of appendages extending from the structures (Figure 1A and 1B). A histogram of the volume distribution of these molecules was fitted with a single peak at $3823 \pm 1857 \mathrm{~nm}^{3}$ (Figure 1C). The diameter of the smallest enclosing circle for this $\mathrm{Mg}^{2+}$ containing buffer was $136 \pm 40 \mathrm{~nm}$ (Figure 1D). The diameter of HCV viral particles has been reported to be about 30-75 $\mathrm{nm}$ [64-74], so the RNA is likely to be compacted 2-5 times more when it is packaged into the capsid.

\section{AFM imaging of HCV RNA secondary structure}

Since $\mathrm{Mg}^{2+}$ is required for many tertiary contacts to form, but not required for the formation of RNA secondary structures formed primarily by Watson-Crick base-pairing [57-59], we should be able to image the secondary structure without the formation of tertiary contacts by diluting the RNA in $\mathrm{Mg}^{2+}$-free buffer. After heating for 2 mins at $65^{\circ} \mathrm{C}$ in this buffer just prior to deposition, the morphology of the RNA was markedly different (Figure 2A and 2B). These RNA molecules had a linearized morphology with various small appendages along the molecule. When the volume of these molecules was analyzed, there was a main peak at $4136 \pm 1768 \mathrm{~nm}^{3}$ (Figure 2C). This is close to the volume of the HCV genome molecules in the $\mathrm{Mg}^{2+}$ buffer (Figure $1 C)$, suggesting that single molecules are observed in both set of conditions. There is also a larger peak in the volume histogram at 8691 $\pm 436 \mathrm{~nm}^{3}$. This suggests that some of the molecules may actually have dimerized in these images. The diameter of the smallest enclosing circle was $219 \pm 63 \mathrm{~nm}$ (Figure 2D), 1.6 times larger than the molecules in the $\mathrm{Mg}^{2+}$-containing buffer.

\section{Structural Analysis of HCV RNA}

To get a better idea of the secondary structure of the HCV RNA molecules, additional dimensional analysis was performed. In Figure 3, two molecules which appeared to have some structural similarities are shown. These two molecules show a common structural characteristic of one end with a blob with a height of about $2 \mathrm{~nm}$ followed by a 35-76 $\mathrm{nm}$ long region of the molecule with heights of about $0.5 \mathrm{~nm}$ (Figure $3 \mathrm{~A}$, left, box outlines). This area likely represents an unpaired single stranded region of the HCV genome. The contour of the molecules extended for lengths of $582 \mathrm{~nm}$ (top) and $470 \mathrm{~nm}$ (bottom). Height profiles for each of these molecules showed 29 peaks (top) or 27 peaks (bottom) with 17 (top) or 16 (bottom) visibly protruding appendages 
Citation: Gilmore JL, Aizaki H, Yoshida A, Deguchi K, Kumeta M, et al. (2014) Nanoimaging of ssRNA: Genome Architecture of the Hepatitis C Virus Revealed by Atomic Force Microscopy. J Nanomed Nanotechol S5: 010. doi:10.4172/2157-7439.S5-010
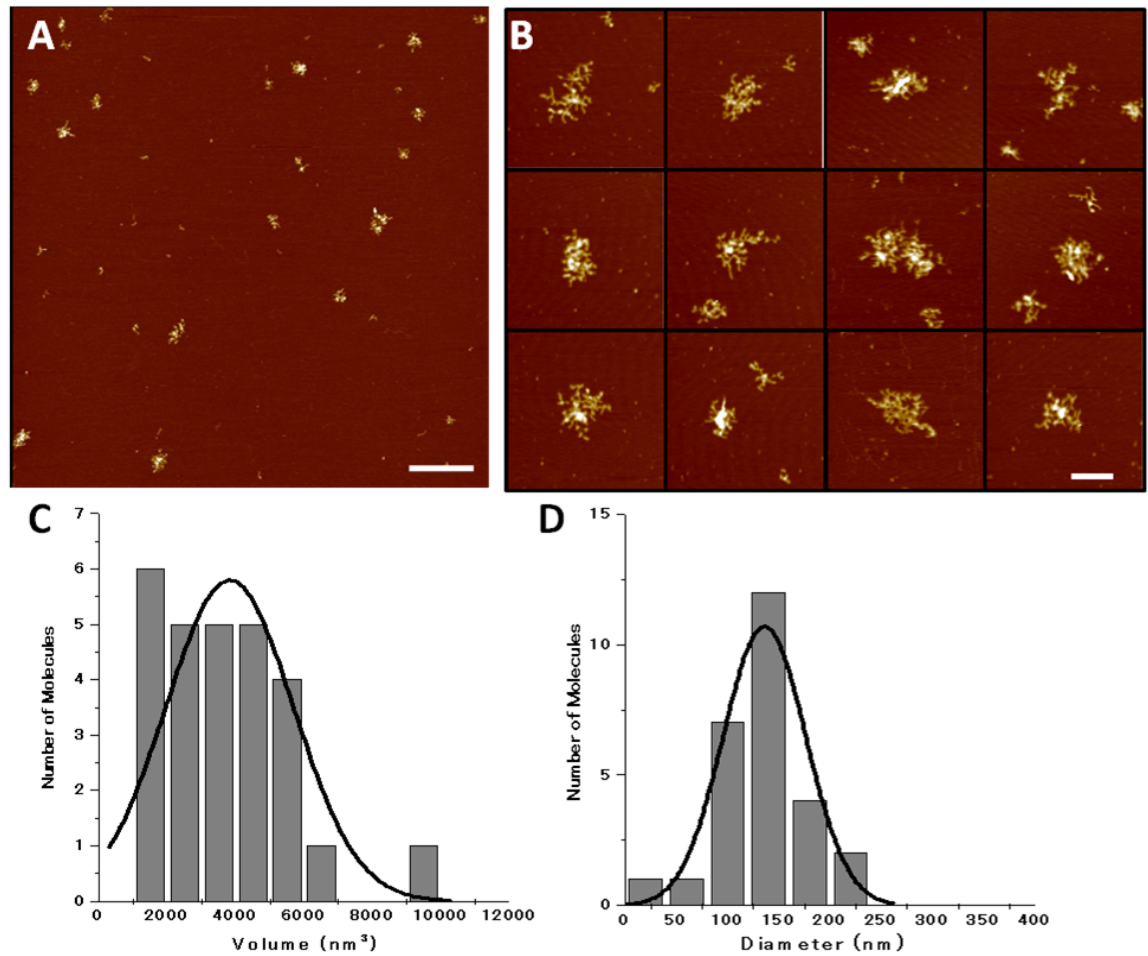

Figure 1: AFM imaging and analysis of HCV RNA deposited in $\mathrm{Mg}^{2+}$-containing buffer. A representative $3 \times 3 \mu \mathrm{m}^{2}$ image $(\mathbf{A}$ scale bar= $0.4 \mu \mathrm{m})$ along with a gallery of $0.4 \times 0.4 \mu \mathrm{m}^{2}$ images (B scale Bar=0.1 $\mathrm{mm}$ ) for RNA deposited in buffer containing $1.5 \mathrm{mM} \mathrm{Mg}^{2+}$ cations. Histograms of the volume $(\mathbf{C})$ and diameter of the smallest enclosing circle (D).
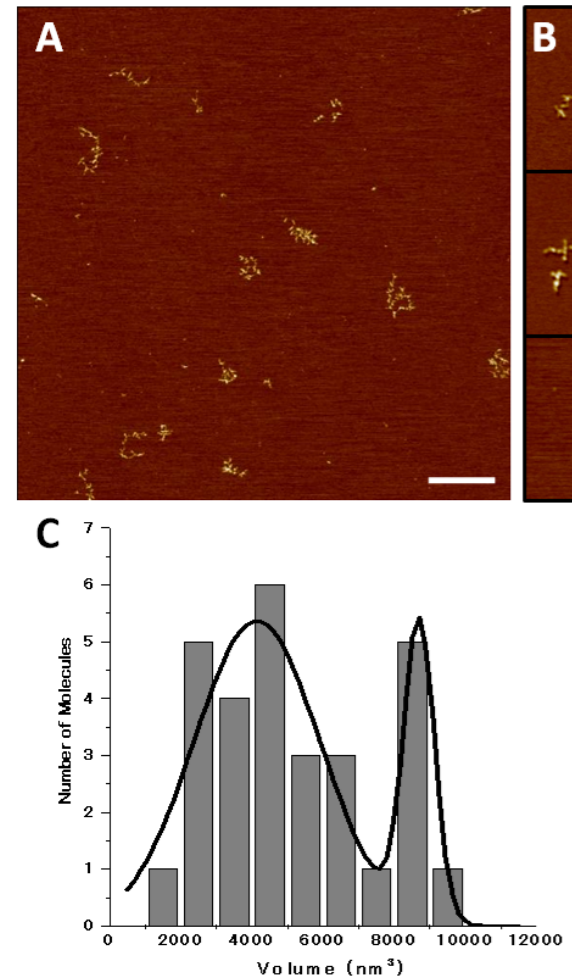

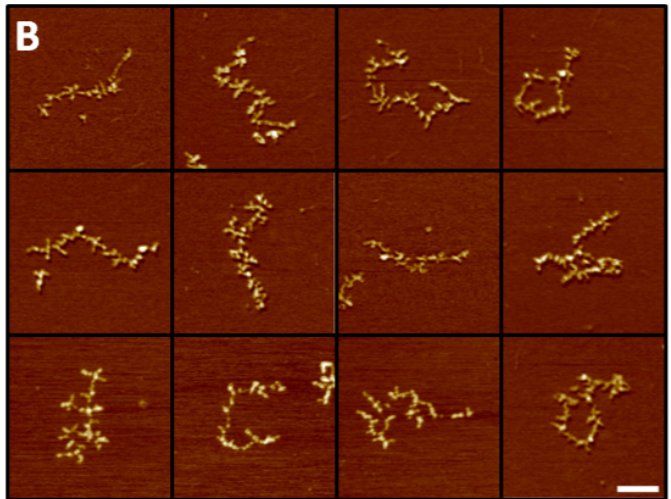

D

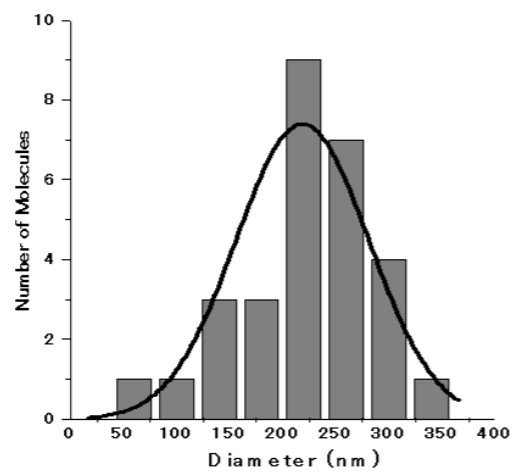

Figure 2: AFM imaging and analysis of HCV RNA deposited in $\mathrm{Mg}^{2+}$-free buffer. A representative $3 \times 3 \mu \mathrm{m}^{2}$ image $(\mathbf{A}$, scale bar $=0.4 \mu \mathrm{m})$ along with a gallery of $0.4 \times 0.4$ $\mu \mathrm{m}^{2}$ images (B, scale Bar=0.1 $\mu \mathrm{m}$ ) for RNA deposited in buffer lacking $\mathrm{Mg}^{2+}$ cations. Histograms of the volume (C) and diameter of the smallest enclosing circle (D). 
Citation: Gilmore JL, Aizaki H, Yoshida A, Deguchi K, Kumeta M, et al. (2014) Nanoimaging of ssRNA: Genome Architecture of the Hepatitis C Virus Revealed by Atomic Force Microscopy. J Nanomed Nanotechol S5: 010. doi:10.4172/2157-7439.S5-010

Page 4 of 7

(Figure 3A, graphs). These values can vary considerably depending on the orientation of the molecule on the mica surface. The other end of the molecules has an appendage-free region with a 'beaded' appearance showing variable structures with heights of about $2-3 \mathrm{~nm}$ preceded by a sharp kinked region (Figure 3A, left, arrows).

Additional molecules displaying this single-stranded morphology are displayed in Figure 3B. A histogram of the length of this single stranded region results in a single peak centered around the value of $58 \pm 8 \mathrm{~nm}$ (Figure 3C). It is likely that this region corresponds to the poly-U/UC region present in this RNA molecule. The poly- $\mathrm{U} / \mathrm{C}$ region is conserved throughout all HCV genotypes, but varies in length [18]. In the JFH-1 genome used in this study, this region is $103 \mathrm{nt}$ long. Varying the length or composition of this region has been reported to effect the efficiency of viral replication [19-21] as well as to influence recognition of the genome by the RIG-I protein which is necessary for the host cell to mount an Interferon (IFN)-mediated immune response to the virus [22-24]. Assuming that this single stranded regions is actually $103 \mathrm{nt}$ long (the whole poly-U/UC region is unpaired and the regions immediately flanking it are paired), it would mean that, according to our measured length $(58 \mathrm{~nm})$, the length per nucleotide of the single stranded region is $0.56 \mathrm{~nm}$. In a previous force measurement study with homopolymeric ribonucleotides, molecules 1500-4000 nt in long were stretched to a length of about $1600 \mathrm{~nm}$. This means that the length per nucleotide should be about $0.4-1.0 \mathrm{~nm}$, in good agreement with our calculated value $[75,76]$. The small blob at the end of the single stranded region is likely the $98 \mathrm{nt} 3^{\prime} \mathrm{X}$-RNA which is a well studied region immediately flanking the poly-U/UC region and has been reported to form either two or three stem loops [35].

\section{Verification of RNA homopolymer morphology and ssRNA volume}

To further verify the morphology of homopolymeric singlestranded RNA with AFM, an 3890 nt importin- $\beta$ ssRNA transcript was also imaged (Figure 4 ). This transcript is not a true mRNA because it lacks the 5' and 3'-UTRs. The importin- $\beta$ ssRNA was prepared by in vitro transcription in two different ways. Initially, the ssRNA was simply transcribed from cDNA with T7 polymerase and directly imaged (Figure 4A). The same RNA was then treated with polyadenylate polymerase to add a random number of adenine residues to the molecules and imaged (Figure 4B). The addition of the poly(A) tail
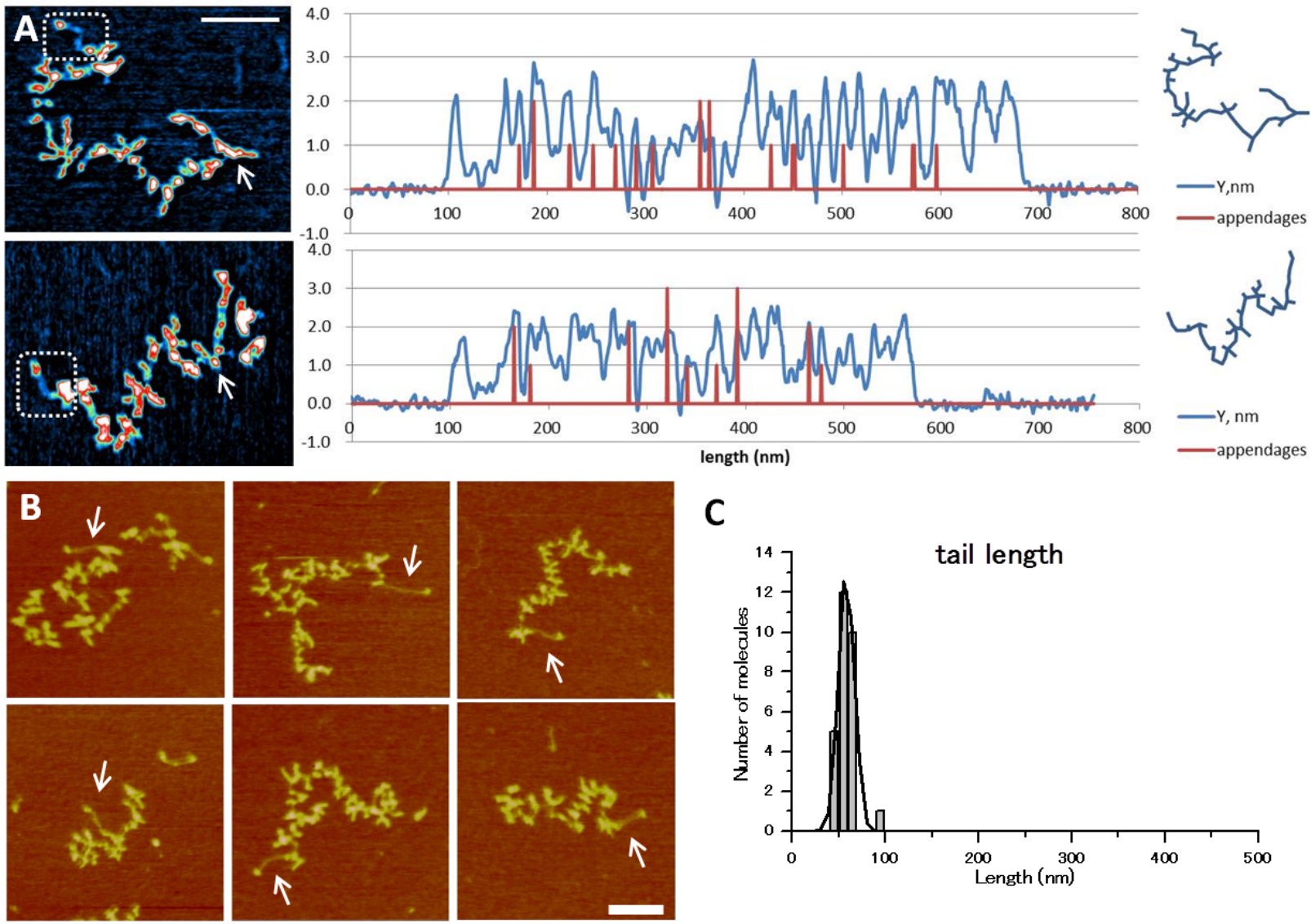

C
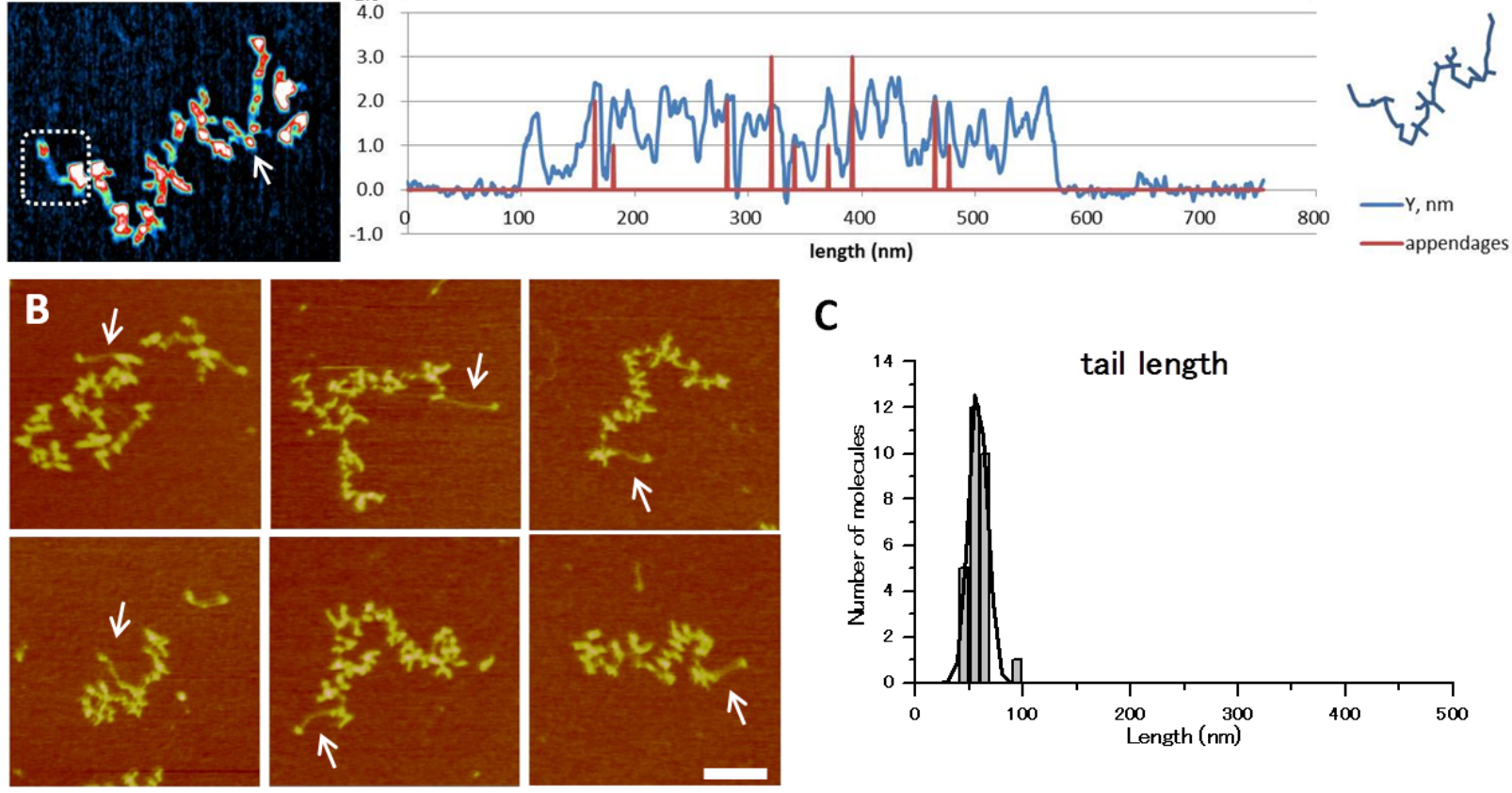

Figure 3: Analysis of HCV RNA secondary structure. (A) Two representative molecules for $\mathrm{Mg}^{2+}$-containing reactions are shown on the left. In these images, black $\sim 0$ $\mathrm{nm}$, blue $\sim 0.5 \mathrm{~nm}$, green $\sim 1.0 \mathrm{~nm}$, red $\sim 1.5 \mathrm{~nm}$, and white $\sim 2 \mathrm{~nm}$ and higher. The single stranded region of the genome is shown in the dotted box. The arrows point to the kinked region of the genome preceding the appendage-free region of the genome. Bar $=80 \mathrm{~nm}$. To the right of each image, a contour plot profile corresponding to each molecule is displayed with the blue line corresponding to the height of features along the length backbone of the molecule and the red line corresponding to the number of appendages protruding out from the molecule along the backbone. Each plot starts at $100 \mathrm{~nm}$ along the background of the image. The molecule is then traced starting from the end outlined with the box in the images at the left. A trace of the molecule is shown to the right of each plot. (B) Six representative $0.4 \times 0.4$ $\mu \mathrm{m}^{2}$ images of molecules exhibiting the single stranded 'tail' morphology at the end of the molecule. Bar=100 $\mathrm{nm}$ (C) A histogram of the length of the tail region of the molecules which exhibited this morphology. 
Citation: Gilmore JL, Aizaki H, Yoshida A, Deguchi K, Kumeta M, et al. (2014) Nanoimaging of ssRNA: Genome Architecture of the Hepatitis C Virus Revealed by Atomic Force Microscopy. J Nanomed Nanotechol S5: 010. doi:10.4172/2157-7439.S5-010

Page 5 of 7

shows a single stranded morphology similar to what was observed for the end of the viral RNA molecules. Along the mainly single stranded region, there are often kinks, or "knobs" and some apparent doublestranded regions. This observation is corroborated by previous AFM imaging which also observed a 'knob' like structures along poly(A) RNA molecules [54]. Additionally, the crystal structure of a poly(A) duplex has been resolved to 1 Å resolution [77].

Measurement of the contour length of the importin- $\beta$ poly $(\mathrm{A})$ tails showed a very broad distribution of values ranging from 40-830 $\mathrm{nm}$ long (Figure 4C). Attempting to fit the broad distribution with a Gaussian curve resulted in a value of $125 \pm 88 \mathrm{~nm}$, suggesting that the majority of the poly(A) tails were about twice as long as observed for the viral RNA and the standard deviation of the distribution is 11 times higher. Although the morphologies of the homopolymeric RNA molecules were similar, past studies have reported results suggesting that homopolymeric chains of different nucleotides do not behave exactly the same. For example, poly $(\mathrm{G})$ forms tetrads [78]. Poly $(\mathrm{C})$ and poly(A) have been reported to form single-stranded helical regions which are reflected by plateaus when the chains are stretched resulting from a helix-coil transistion. However, when $\operatorname{poly}(\mathrm{U})$ is stretched, there are no plateaus, suggesting that it does not form helical domains [76].
Verification that the viral ssRNA structures we observed represent the full viral genome comes from comparing the measured volumes in of various ssRNA molecules to their molecular weight. The graph in Figure 4D shows how the measured volumes of four different kinds of ssRNA molecules relates to their length in nucleotides. The four molecules analyzed include the HCV RNA $\left(3823 \pm 1857 \mathrm{~nm}^{3}\right)$, the importin- $\beta$ ssRNA without the poly(A) tail $\left(1930 \pm 437 \mathrm{~nm}^{3}\right)$, the $28 \mathrm{~S}$ ribosomal (r)RNA $\left(2688 \pm 655 \mathrm{~nm}^{3}\right)$, and the $18 \mathrm{~S}$ rRNA $(921 \pm 527$ $\mathrm{nm}^{3}$ ). By fitting these points with a linear regression curve, the volume measured using our method increases by $0.4 \mathrm{~nm}^{3}$ per nucleotide of RNA. Images of the $18 \mathrm{~S}$ and $28 \mathrm{~S}$ rRNA molecules are shown in Figure $4 \mathrm{E}$ for reference.

\section{Perspective}

The ability of AFM to visualize $\mathrm{Mg}^{2+}$-dependent structural changes of RNA opens up an exciting range of possibilities for what AFM can reveal about RNA in the future. For example, the ability of AFM to image molecules in aqueous environments opens up the exciting possibility of visualizing the folding/unfolding transitions of RNA using highspeed AFM (HS-AFM) [41-45]. Additionally, further refinement of the structural models could be gained by imaging individual portions of the
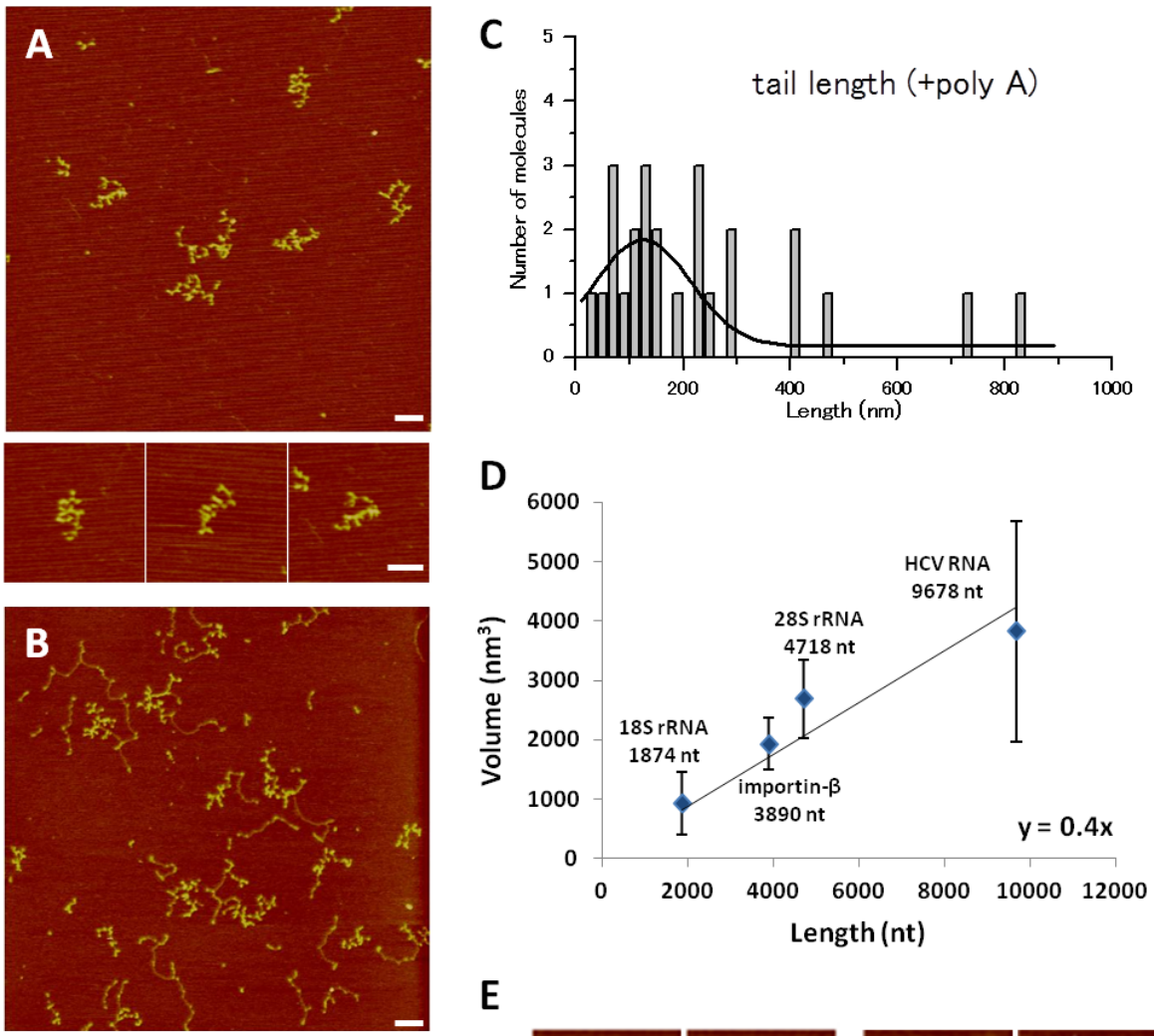

E
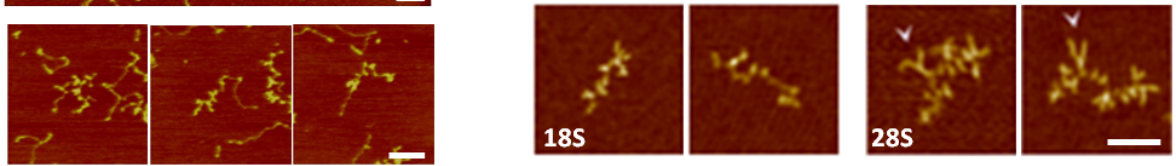

Figure 4: Imaging and analysis of importin- $\beta$ ssRNA secondary structure. Representative $1.5 \times 1.5 \mu \mathrm{m}^{2}$ images with a gallery of three $0.4 \times 0.4 \mu \mathrm{m}^{2}$ images of importin- $\beta$ mRNA without (A) and with (B) the poly (A) tail. (C) A histogram of the length of the poly(A) tail of the molecules in (B). (D) A graph demonstrating how the length of four different SsRNA molecules relates to the measured volume. Bars represent the standard deviation of the gaussian distribution. (E) Representative images of $18 S$ and $28 \mathrm{~S}$ rRNA molecules. All scale bars $=100 \mathrm{~nm}$. 
Citation: Gilmore JL, Aizaki H, Yoshida A, Deguchi K, Kumeta M, et al. (2014) Nanoimaging of ssRNA: Genome Architecture of the Hepatitis C Virus Revealed by Atomic Force Microscopy. J Nanomed Nanotechol S5: 010. doi:10.4172/2157-7439.S5-010

RNA. Comparing these individual domains may aid in understanding how their structures relate to the structures observed in the full viral genome. Additionally, labeling strategies could be used to identify where a particular sequence may occur along an RNA backbone. In addition to labels, the interaction of various RNA-binding proteins with various RNA structures can also be studied. If a method to attach a RNA-binding protein or chemical to the AFM tip can be developed, recognition imaging [79-82] may also be used to assess which structural features of an RNA molecule the ligand interacts with. Also, proteins can be imaged along with the RNA to observe the effect they have on the viral structure. The ability of AFM to visualize global structural rearrangements of RNA may be a promising tool to investigate the role of RNA structures in viral processes for future studies, which could provide us with an understanding of how to control the spread of the virus in infected individuals.

\section{Acknowledgements}

R.W and K.T. are supported by a Grant-in-Aid for Scientific Research on Innovative Areas "Molecular basis of host cell competency in virus infection" (\#24115003) from MEXT Japan. M.K. is supported by a Grant-in-Aid for Scientific Research on Innovative Areas "Spying minority in biological phenomena" (\#24115512) from MEXT Japan.

\section{References}

1. World Health Organization (2013) Hepatitis C Fact Sheet no. 164. Geneva Switzerland.

2. Zhu Y, Chen S (2013) Antiviral treatment of hepatitis $C$ virus infection and factors affecting efficacy. World J Gastroenterol 19: 8963-8973.

3. Choo QL, Kuo G, Weiner a J, Overby LR, Bradley DW, et al. (1989) Isolation of a cDNA clone derived from a blood-borne non-A, non-B viral hepatitis genome. Science 244: 359-362.

4. Tsukiyama-Kohara K1, lizuka N, Kohara M, Nomoto A (1992) Internal ribosome entry site within hepatitis C virus RNA. J Virol 66: 1476-1483.

5. Brown EA, Zhang H, Ping LH, Lemon SM (1992) Secondary structure of the 5 ' nontranslated regions of hepatitis $\mathrm{C}$ virus and pestivirus genomic RNAs. Nucleic Acids Res 20: 5041-5045.

6. Wang C, Le SY, Ali N, Siddiqui A (1995) An RNA pseudoknot is an essential structural element of the internal ribosome entry site located within the hepatitis C virus 5' noncoding region. RNA 1: 526-537.

7. Honda M, Ping LH, Rijnbrand RC, Amphlett E, Clarke B, et al. (1996) Structura requirements for initiation of translation by internal ribosome entry within genome-length hepatitis C virus RNA. Virology 222: 31-42.

8. Kieft JS, Zhou K, Jubin R, Murray MG, Lau JY, et al. (1999) The hepatitis C virus internal ribosome entry site adopts an ion-dependent tertiary fold. J Mol Biol 292: 513-529.

9. Lukavsky PJ, Otto GA, Lancaster AM, Sarnow P, Puglisi JD (2000) Structures of two RNA domains essential for hepatitis $C$ virus internal ribosome entry site function. Nat Struct Biol 7: 1105-1110.

10. Kieft JS, Zhou K, Grech A, Jubin R, Doudna JA (2002) Crystal structure of an RNA tertiary domain essential to HCV IRES-mediated translation initiation. Nat Struct Biol 9: 370-374.

11. Kim I1, Lukavsky PJ, Puglisi JD (2002) NMR study of 100 kDa HCV IRES RNA using segmental isotope labeling. J Am Chem Soc 124: 9338-9339.

12. Lukavsky PJ1, Kim I, Otto GA, Puglisi JD (2003) Structure of HCV IRES domain II determined by NMR. Nat Struct Biol 10: 1033-1038.

13. Kieft JS (2008) Viral IRES RNA structures and ribosome interactions. Trends Biochem Sci 33: 274-283.

14. Rijnbrand R, Thiviyanathan V, Kaluarachchi K, Lemon SM, Gorenstein DG (2004) Mutational and structural analysis of stem-loop IIIC of the hepatitis C virus and GB virus B internal ribosome entry sites. J Mol Biol 343: 805-817.

15. Lukavsky PJ (2009) Structure and function of HCV IRES domains. Virus Res 139: 166-171.

16. Berry KE, Waghray S, Mortimer SA, Bai Y, Doudna JA (2011) Crystal structure of the HCV IRES central domain reveals strategy for start-codon positioning. Structure 19: 1456-1466.
17. Pérard J, Leyrat C, Baudin F, Drouet E, Jamin M (2013) Structure of the fulllength HCV IRES in solution. Nat Commun 4: 1612.

18. Kolykhalov AA, Feinstone SM, Rice CM (1996) Identification of a highly conserved sequence element at the 3 ' terminus of hepatitis $C$ virus genome RNA. These include?: Identification of a Highly Conserved Sequence Element at the 3? Terminus of Hepatitis C Virus Genome RNA. 70: 3363-3371.

19. Friebe $P$, Bartenschlager $R$ (2002) Genetic analysis of sequences in the $3^{\prime}$ nontranslated region of hepatitis $\mathrm{C}$ virus that are important for RNA replication. J Virol 76: 5326-5338.

20. Yi M, Lemon SM (2003) 3' nontranslated RNA signals required for replication of hepatitis C virus RNA. J Virol 77: 3557-3568.

21. You S, Rice CM (2008) 3' RNA elements in hepatitis C virus replication: kissing partners and long poly(U). J Virol 82: 184-195.

22. Saito T, Owen DM, Jiang F, Marcotrigiano J, Gale M Jr (2008) Innate immunity induced by composition-dependent RIG-I recognition of hepatitis $C$ virus RNA. Nature 454: 523-527.

23. Uzri D, Gehrke L (2009) Nucleotide sequences and modifications that determine RIG-I/RNA binding and signaling activities. J Virol 83: 4174-4184.

24. Schnell G, Loo YM, Marcotrigiano J, Gale M Jr (2012) Uridine composition of the poly-U/UC tract of HCV RNA defines non-self recognition by RIG-I. PLoS Pathog 8: e1002839.

25. Tuplin A, Wood J, Evans DJ, Patel AH, Simmonds P (2002) Thermodynamic and phylogenetic prediction of RNA secondary structures in the coding region of hepatitis C virus. RNA 8: 824-841.

26. You S, Stump DD, Branch AD, Rice CM (2004) A cis-acting replication element in the sequence encoding the NS5B RNA-dependent RNA polymerase is required for hepatitis $C$ virus RNA replication. J Virol 78: 1352-1366.

27. Lee $H$, Shin $H$, Wimmer E, Paul AV (2004) cis-acting RNA signals in the NS5B C-terminal coding sequence of the hepatitis $\mathrm{C}$ virus genome. J Virol 78: 10865 10877.

28. Tuplin a, Evans DJ, Simmonds $P$ (2004) Detailed mapping of RNA secondary structures in core and NS5B-encoding region sequences of hepatitis $C$ virus by RNase cleavage and novel bioinformatic prediction methods. J Gen Virol 85: 3037-3047.

29. Zhang J, Yamada O, Sakamoto T, Yoshida H, Araki H, et al. (2005) Inhibition of hepatitis $\mathrm{C}$ virus replication by pol III-directed overexpression of RNA decoys corresponding to stem-loop structures in the NS5B coding region. Virology 342 276-285.

30. Friebe P, Boudet J, Simorre JP, Bartenschlager R (2005) Kissing-loop interaction in the 3 ' end of the hepatitis $C$ virus genome essential for RNA replication. J Virol 79: 380-392

31. Diviney S, Tuplin A, Struthers M, Armstrong V, Elliott RM, et al. (2008) A hepatitis $C$ virus cis-acting replication element forms a long-range RNA-RNA interaction with upstream RNA sequences in NS5B. J Virol 82: 9008-9022.

32. Romero-López C, Berzal-Herranz A (2009) A long-range RNA-RNA interaction between the 5' and 3' ends of the HCV genome. RNA 15: 1740-1752.

33. Shetty S, Kim S, Shimakami T, Lemon SM, Mihailescu MR (2010) Hepatitis C virus genomic RNA dimerization is mediated via a kissing complex intermediate. RNA 16: 913-925.

34. Tuplin A, Struthers M, Simmonds P, Evans DJ (2012) A twist in the tail: SHAPE mapping of long-range interactions and structural rearrangements of RNA elements involved in HCV replication. Nucleic Acids Res 40: 6908-6921.

35. Shetty S, Stefanovic S, Mihailescu MR (2013) Hepatitis C virus RNA: molecular switches mediated by long-range RNA-RNA interactions? Nucleic Acids Res 41: 2526-2540.

36. Jaeger JA, SantaLucia J Jr, Tinoco I Jr (1993) Determination of RNA structure and thermodynamics. Annu Rev Biochem 62: 255-287.

37. Hansma PK, Elings VB, Marti O, Bracker CE (1988) Scanning tunneling microscopy and atomic force microscopy: application to biology and technology. Science 242: 209-216.

38. Binnig G, Quate CF, Gerber C (1986) Atomic force microscope. Phys Rev Let 56: 930-933.

39. Suzuki Y, Yoshikawa Y, Yoshimura SH, Yoshikawa K, Takeyasu K (2011) Unraveling DNA dynamics using atomic force microscopy. Wiley Interdiscip Rev Nanomed Nanobiotechnol. 
Citation: Gilmore JL, Aizaki H, Yoshida A, Deguchi K, Kumeta M, et al. (2014) Nanoimaging of ssRNA: Genome Architecture of the Hepatitis C Virus Revealed by Atomic Force Microscopy. J Nanomed Nanotechol S5: 010. doi:10.4172/2157-7439.S5-010

40. Shlyakhtenko LS, Gilmore J, Portillo A, Tamulaitis G, Siksnys V, et al. (2007) Direct visualization of the EcoRII-DNA triple synaptic complex by atomic force microscopy. Biochemistry 46: 11128-11136.

41. Crampton N, Yokokawa M, Dryden DT, Edwardson JM, Rao DN, et al. (2007) Fast-scan atomic force microscopy reveals that the type III restriction enzyme EcoP15I is capable of DNA translocation and looping. Proc Natl Acad Sci U S A 104: 12755-12760.

42. Gilmore JL, Suzuki Y, Tamulaitis G, Siksnys V, Takeyasu K, et al. (2009) Single-molecule dynamics of the DNA-EcoRII protein complexes revealed with high-speed atomic force microscopy. Biochemistry 48: 10492-10498.

43. Suzuki Y, Higuchi Y, Hizume K, Yokokawa M, Yoshimura SH, et al. (2010) Molecular dynamics of DNA and nucleosomes in solution studied by fastscanning atomic force microscopy. Ultramicroscopy 110: 682-688.

44. Suzuki Y, Gilmore JL, Yoshimura SH, Henderson RM, Lyubchenko YL, et al. (2011) Visual analysis of concerted cleavage by type IIF restriction enzyme Sfi in subsecond time region. Biophys J 101: 2992-2998.

45. Sanchez H, Suzuki Y, Yokokawa M, Takeyasu K, Wyman C (2011) ProteinDNA interactions in high speed AFM: single molecule diffusion analysis of human RAD54. Integr Biol (Camb) 3: 1127-1134

46. Suzuki Y, Endo M, Katsuda Y, Ou K, Hidaka K, et al. (2014) DNA origam based visualization system for studying site-specific recombination events. J Am Chem Soc 136: 211-218.

47. Suzuki Y, Endo M, Yang Y, Sugiyama H (2014) Dynamic assembly/disassembly processes of photoresponsive DNA origami nanostructures directly visualized on a lipid membrane surface. J Am Chem Soc 136: 1714-1717.

48. Noestheden M, Hu Q, Tonary AM, Tay LL, Pezacki JP (2007) Evaluation of chemical labeling strategies for monitoring HCV RNA using vibrational microscopy. Org Biomol Chem 5: 2380-2389.

49. Chernov KG, Curmi PA, Hamon L, Mechulam A, Ovchinnikov LP, et al. (2008) Atomic force microscopy reveals binding of mRNA to microtubules mediated by two major mRNP proteins YB-1 and PABP. FEBS Lett 582: 2875-2881.

50. Davis M, Sagan SM, Pezacki JP, Evans DJ, Simmonds P (2008) Bioinformatic and physical characterizations of genome-scale ordered RNA structure in mammalian RNA viruses. J Virol 82: 11824-11836.

51. Sagan SM, Nasheri N, Luebbert C, Pezacki JP (2010) The efficacy of siRNAs against hepatitis $C$ virus is strongly influenced by structure and target site accessibility. Chem Biol 17: 515-527.

52. Wu B1, Grigull J, Ore MO, Morin S, White KA (2013) Global organization of a positive-strand RNA virus genome. PLoS Pathog 9: e1003363.

53. Hansma HG1, Revenko I, Kim K, Laney DE (1996) Atomic force microscopy of long and short double-stranded, single-stranded and triple-stranded nucleic acids. Nucleic Acids Res 24: 713-720.

54. Smith BL, Gallie DR, Le H, Hansma PK (1997) Visualization of poly(A)-binding protein complex formation with poly(A) RNA using atomic force microscopy. J Struct Biol 119: 109-117.

55. Kuznetsov YG, Daijogo S, Zhou J, Semler BL, McPherson A (2005) Atomic force microscopy analysis of icosahedral virus RNA. J Mol Biol 347: 41-52.

56. Archer EJ, Simpson MA, Watts NJ, O'Kane R, Wang B, et al. (2013) Longrange architecture in a viral RNA genome. Biochemistry 52: 3182-3190.

57. Brion P, Westhof E (1997) Hierarchy and dynamics of RNA folding. Annu Rev Biophys Biomol Struct 26: 113-137.

58. Tinoco I Jr, Bustamante C (1999) How RNA folds. J Mol Biol 293: 271-281.

59. Draper DE (2004) A guide to ions and RNA structure. RNA 10: 335-343.

60. Kato T, Furusaka A, Miyamoto M, Date T, Yasui K, et al. (2001) Sequence analysis of hepatitis $\mathrm{C}$ virus isolated from a fulminant hepatitis patient. J Med Virol 64: 334-339.

61. Kato T, Date T, Miyamoto M, Furusaka A, Tokushige K, et al. (2003) Efficient replication of the genotype $2 \mathrm{a}$ hepatitis $\mathrm{C}$ virus subgenomic replicon. Gastroenterology 125: 1808-1817

62. Kato T, Date T, Murayama A, Morikawa K, Akazawa D, et al. (2006) Cell culture and infection system for hepatitis $\mathrm{C}$ virus. Nat Protoc 1: 2334-2339.

63. Wakita T (2009) Isolation of JFH-1 strain and development of an HCV infection system. Methods Mol Biol 510: 305-327.
64. He LF, Alling D, Popkin T, Shapiro M, Alter HJ, et al. (1987) Determining the size of non-A, non-B hepatitis virus by filtration. $J$ Infect Dis 156: 636-640.

65. Yuasa T, Ishikawa G, Manabe S, Sekiguchi S, Takeuchi K, et al. (1991) The particle size of hepatitis $C$ virus estimated by filtration through microporous regenerated cellulose fibre. J Gen Virol 72: 2021-2024.

66. Takahashi $\mathrm{K}$, Kishimoto $\mathrm{S}$, Yoshizawa $\mathrm{H}$, Okamoto $\mathrm{H}$, Yoshikawa $\mathrm{A}$, et al. (1992) p26 protein and 33-nm particle associated with nucleocapsid of hepatitis $C$ virus recovered from the circulation of infected hosts. Virology 191: 431-434.

67. Kaito M, Watanabe S, Tsukiyama-Kohara K, Yamaguchi K, Kobayashi Y, et al. (1994) Hepatitis C virus particle detected by immunoelectron microscopic study. J Gen Virol 75: 1755-1760.

68. Shimizu YK, Feinstone SM, Kohara M, Purcell RH, Yoshikura H (1996) Hepatitis C virus: detection of intracellular virus particles by electron microscopy. Hepatology 23: 205-209

69. Wakita T, Pietschmann T, Kato T, Date T, Miyamoto M, et al. (2005) Production of infectious hepatitis $C$ virus in tissue culture from a cloned viral genome. Nat Med 11: 791-796.

70. Gastaminza P, Kapadia SB, Chisari FV (2006) Differential biophysica properties of infectious intracellular and secreted hepatitis $C$ virus particles. $J$ Virol 80: 11074-11081

71. Yu X, Qiao M, Atanasov I, Hu Z, Kato T, et al. (2007) Cryo-electron microscopy and three-dimensional reconstructions of hepatitis $\mathrm{C}$ virus particles. Virology 367: 126-134.

72. Nielsen SU, Bassendine MF, Martin C, Lowther D, Purcell PJ, et al. (2008) Characterization of hepatitis $C$ RNA-containing particles from human liver by density and size. J Gen Virol 89: 2507-2517.

73. Gastaminza P, Dryden KA, Boyd B, Wood MR, Law M, et al. (2010) Ultrastructural and biophysical characterization of hepatitis $C$ virus particles produced in cell culture. J Virol 84: 10999-11009.

74. Catanese MT, Uryu K, Kopp M, Edwards TJ, Andrus L, et al. (2013) Ultrastructural analysis of hepatitis $C$ virus particles. Proc Natl Acad Sci U S A 110: 9505-9510.

75. Seol Y, Skinner GM, Visscher K (2004) Elastic properties of a single-stranded charged homopolymeric ribonucleotide. Phys Rev Lett 93: 118102.

76. Seol Y, Skinner GM, Visscher K, Buhot A, Halperin A (2007) Stretching of homopolymeric RNA reveals single-stranded helices and base-stacking. Phys Rev Lett 98: 158103

77. Safaee N, Noronha AM, Rodionov D, Kozlov G, Wilds CJ, et al. (2013) Structure of the parallel duplex of poly(A) RNA: evaluation of a 50 year-old prediction. Angew Chem Int Ed Engl 52: 10370-10373.

78. Arnott S, Chandrasekaran R, Marttila CM (1974) Structures for polyinosinic acid and polyguanylic acid. Biochem $\mathrm{J}$ 141: 537-543.

79. Kienberger F, Ebner A, Gruber HJ, Hinterdorfer P (2006) Molecular recognition imaging and force spectroscopy of single biomolecules. Acc Chem Res 39 29-36

80. Dufrêne YF, Hinterdorfer P (2008) Recent progress in AFM molecular recognition studies. Pflugers Arch 456: 237-245.

81. Hirano $Y$, Takahashi $H$, Kumeta M, Hizume K, Hirai Y, et al. (2008) Nuclea architecture and chromatin dynamics revealed by atomic force microscopy in combination with biochemistry and cell biology. Pflugers Arch 456: 139-153.

82. Takahashi H, Hizume K, Kumeta M, H Yoshimura S, Takeyasu K (2009) Single-molecule anatomy by atomic force microscopy and recognition imaging Arch Histol Cytol 72: 217-225.

This article was originally published in a special issue, Nanotechnology Challenges \& Perspectives in Medicine handled by Editor(s). Dr. Malavosklish Bikram, University of Houston, USA 